\title{
Model Ibadah Sekolah Minggu Kreatif-Interaktif bagi Generasi Alfa di Gereja Toraja
}

\author{
Daniel Fajar Panuntun ${ }^{1}$, Rinaldus Tanduklangi, Merry Adeng, Christian Eleyazar Randalele \\ Sekolah Tinggi Agama Kristen Negeri Toraja, Tana Toraja, Sulawesi Selatan \\ 1_daniel_fp@stakntoraja.ac.id
}

\begin{abstract}
Industrial revolution 4.0 is bringing great impact into the global world, including children from the alpha generation. The alpha generation have a typical characteristic that need to gain a concern in terms of spiritual needs. Sunday schol expecially Toraja's Church need to do an inovation to fulfill the spiritual need of The alpha generation. This study use Research and Development (RnD) method. The research produce a product which is a book with the tittle Sekolah Minggu KreatifInovatif.The book is produced by a kualitatif approach with interactive analysis. The development of the product is done by critism of participant about the product. The result is a Sekolah Minggu Kreatif-Inovatif book For the alfa generation of Toraja's Church with the collaborative and confrontative principle.
\end{abstract}

Keyword: alpha generation; church of Toraja; revolution industri 4.0; Sunday school

\begin{abstract}
Abstrak: Revolusi Industri 4.0 menghasilkan pengaruh besar bagi dunia global, salah satunya pada anak-anak generasi alfa.Anak-anak generasi alfa memiliki ciri khas yang perlu untuk mendapatkan perhatian dalam hal kebutuhan rohaninya. Sekolah Minggu terkhusus di Gereja Toraja perlu untuk melakukan inovasi untuk menjawab kebutuhan rohani anak-anak generasi alfa. Kajian ini menggunakan jenis penelitian dan pengembangan (RnD). Penelitian menghasilkan produk buku Sekolah Minggu Kreatif-Inovatif yang dihasilkan melalui pendekatan kualitatif dengan analisis interaktif. Pengembangan produk dilakukan dengan kristisi partisipan mengenai hasil produk yang dihasilkan.Hasil Akhir adalah buku Sekolah Minggu KreatifInovatif bagi Generasi Alfa Gereja Toraja berdasarkan prinsip kolaboratif dan konfrontatif.
\end{abstract}

Kata Kunci: generasi alfa; revolusi industri 4.0; sekolah minggu; Gereja Toraja

\begin{tabular}{llll}
\hline Article History : & Received: 14-08-2019 & Revised: None & Accepted: 12-12-2019
\end{tabular}

\section{Pendahuluan}

Globalisasi dunia beranjak kepada era yang dikenal dengan sebutan era Revolusi Industri 4.0. Revolusi Industri 4.0 merupakan perubahan industri ke-4, hal ini menyebabkan banyak perubahan yaitu optimasi robot dan mesin dalam setiap dunia industri dengan sistem konektivitas dan digitalisasinya. ${ }^{1}$ Era ini sangat berpengaruh global ke segala penjuru dunia terkhusus berimbas pada kelangsungan hidup bangsa Indonesia.

1Venti Eka Satya, “Strategi Indonesia Menghadapi Industri 4.0."Jurnal Info Singkat: Kajian Singkat Terhadap Isu Aktual dan Strategis. Vol , No 09.(Mei, 2018) 19-20. 
Revolusi Industri 4.0. berdampak besar kepada kehidupan bangsa Indonesia terkhusus pada bidang pendidikan. Hal ini akan dapat menghasilkan tantangan dan peluang bagi bidang pendidikan di Indonesia. ${ }^{2}$ Berdasarkan hal tersebut perlu dipikirkan ulang pendidikan yang tepat bagi generasi Alfa, yaitu generasi yang lahir pada tahun 2010 ke atas dan tidak terlalu jauh berbeda dengan karakter generasi $\mathrm{Z}^{3}$ yang akan mengalami dampak dari generasi ini. Maksimalisasi pendidikan sangat perlu ditujukan dengan modifikasi prinsip, pola/model, dan strategi agar anak-anak generasi alfa dapat survive di era ini.

Berbagai penelitian mengenai generasi alfa dan pekembangannya sangat banyak dikembangkan. Beberapa penilitian tersebut diantaranya adalah: Pengasuhan secara digital yang diperuntukan untuk generasi alfa oleh purnama, ${ }^{4}$ Suatu rancangan buku interaktif untuk perkembangan anak generasi alfa oleh Indrayana et al,5 Penelitiian mengenai Guru ideal bagi generasi alfa oleh kharisma , ${ }^{6}$ Pengembangan pesantren pada era revolusi industri 4.0 dan untuk generasi alfa oleh gazali ${ }^{7}$ dan lainnya. Generasi alfa dan generasi $\mathrm{z}$ yang merupakan generasi sebelumnya mendapat sebutan lain yaitu generasi milenial. ${ }^{8}$ Generasi menjadi bahan kajian yang penting dan aktual pada Era Revolusi Industri 4.0. Kesimpulan dari adanya berbagai penelitian mengenai generasi alfa dan perkembangannya menjadikan penelitian mengenai generasi alfa merupakan penelitian yang penting dan perlu untuk dikaji. Penelitian mengenai generasi ini dapat dilakukan secara multidisplin sehingga menjawab berbagai tantangan dan permasalahan yang ada mengenai generasi alfa ini.

Dampak Revolusi Industri 4.0 berpengaruh pada bidang pendidikan anak generasi alfa, bukan hanya pada pendidikan formal/sekuler namun juga pada pendidikan informal/ rohani. Salah satu pendidikan rohani anak-anak beragama Kristen generasi alfa adalah sekolah minggu. Sekolah minggu merupakan salah satu bentuk ibadah anak. Ibadah merupakan suatu bentuk pengalaman bukan hanya bersifat filosofis mapun intelektual. Ibadah Kristen melibatkan perasaan dan tindakan manusia berkenaan dengan Tuhan. ${ }^{9}$ Ibadah Kristen juga mengandung banyak unsur pendidikan. Unsur

\footnotetext{
2Muhammad Yahya,"Era Industri 4.0.Tantangan dan Peluang Perkembangan Pendidikan Kejuruan Inonesia", (Orasi Ilmiah Senat Universitas Negeri Makassar,Makassar, 14 Maret 2018), 9.

${ }^{3}$ M.McCrindle, The ABC of XYZ. (Australia:UNSW Press,2011).

${ }^{4}$ Sigit Purnama, "Pengasuhan Digital untuk Anak Generasi Alpha", Jurnal Al Hikmah Proc Islamic Ear Child Educ, Vol 1 (Aprili, 2018), 493.

${ }^{5}$ Marrisa Leviani Indrayana et al, "Perancangan Buku Interaktif Pembelajaran Pengembangan Karakter Pada Generasi Alfa”, Jurnal DKV Adiwarna, Vol 1, No 12, (2018),1.

${ }^{6}$ Nanda Veruna Enun Kharisma, "Kriteria Guru Sekolah Dasar ideal Pada Era Generasi Alfa", diakses dari nandaverunaenun.blogs.uny.ac.id/.../Kriteria-Guru-Sekolah-Dasar- 8 Juli 2019, 22.34 WIB

${ }^{7}$ Erfan Gazali, "Pesantren di Antara Generasi Alfa dan Tantangan Dunia PendidikanEra Revolusi Indrustri 4.0.,"Oasis:Jurnal Ilmiah Kajian Islam, Vol 2, No 2, (Februari, 2018), 94.

${ }^{8}$ Tika Mutia, " Generasi Millenial, Instagram dan Dramaturgi: Suatu Fenomena dalam Pengelolan Kesan Ditinjau dari Perspektif Komunikasi Islam," Jurnal Pemikiran Islam, Vol 41, No 2, (Desember, 2017), 240

${ }^{9}$ Laksmi Kusuma Wardani, "Simbolisme Liturgi Ekaristi Dalam Gereja Katolik Sebuah Konsepsi dan Aplikasi Simbol”, Dimensi Interior, Vol.4, No.1, Juni 2006, hal. 18.
} 
pendidikan itu dapat dilihat dari Ibadah maupun Liturginya. ${ }^{10}$ Sekolah Minggu merupakan pendidikan rohani anak yang sangat penting pada masa kini.

Liturgi dan Ibadah pada sekolah minggu perlu dilakukan penelitian dan pengembangan dalam keterkaitannya dengan pendidikan anak generasi alfa pada era Revolusi Industri 4.0. Penelitian hendaknya di fokuskan pada model ibadah dan liturgi yang berkaitan dengan prisip, pola-pola, dan strategi yang perlu dikembangkan agar pendidikan rohani anak pada generasi Alfa menjadi maksimal.

Penelitian ini didasari dari suatu rumusan masalah penelitian yaitu bagaimana penelitian dan pengembangan model Ibadah dan liturgi sekolah minggu bagi generasi alfa pada Gereja Toraja. Tujuan dari penelitian ini adalah untuk mengetahui mendapatkan produk berupa model ibadah dan liturgi bagi generasi alfa pada Gereja Toraja. Manfaat dari penelitian ini adalah: pertama, mendapatkan produk yang berupa model ibadah dan liturgi yang praktis dan dapat diaplikasikan pada sekolah minggu Gereja Toraja. Kedua, memaksimalkan pendidikan rohani pada sekolah minggu Gereja Toraja. Ketiga, mengembangkan ibadah sekolah minggu Gereja Toraja.

\section{Metode Penelitian}

Metode penelitian yang digunakan pada penelitian ini adalah metode penelitian dan pengembangan. ${ }^{11}$ Bagian penelitian dilakukan dengan melakukan observasi, pengumpulan data dan melakukan analisis interaktif ${ }^{12}$ dengan mereduksi dan menyimpulkan hingga terbentuk produk yaitu model ibadah dan liturgi sekolah minggu Gereja Toraja. Bagian pengembangan dilakukan dengan evaluasi pada aspek pertama, desain liturgi dan ibadah. Kedua, pada aspek kesesuaian dengan konteks generasi alfa Gereja Toraja. Hasil evaluasi digunakan untuk mengembangkan produk yang berupa model ibadah dan liturgi sekolah minggu bagi generasi alfa pada Gereja Toraja.

Pengumpulan data untuk bagian penelitian dilakukan dengan langkah-langkah: Pertama, mengumpulkan data terkait dengan Revolusi Industri 4.0. dan pengaruhnya terhadap karakter generasi alfa. Kedua, Sekolah minggu pada Gereja Toraja. Ketiga metode sekolah minggu pada $M E B I G$ Jepang dan SUPERBOOK. Keempat, adalah analisis interaktif untuk penyusunan model ibadah dan liturgi Sekolah Minggu bagi generasi Alfa pada Gereja Toraja.

Pengumpulan data untuk bagian pengembangan dilakukan dengan evaluasi partisipan yaitu: Pertama, pada aspek desain liturgi dan ibadah yaitu oleh merry adeng. Evaluasi ini merupakan langkah uji coba produk atau model yang dibentuk secara terbatas. Kedua, pada aspek konteks generasi alfa pada gereja Toraja yaitu oleh Christian Randalele. Ketiga evaluasi ditambahkan untuk memperbaiki produk sehingga

10Daniel Nuhamara, Pembimbing PAK. (Bandung: Jurnal Info Media, 2007), 77.

${ }^{11}$ Sugiyono, Metode Penelitian Kuantitatif, Kualitatif, dan RnD, (Bandung : Alfabeta, 2009), 297

${ }^{12}$ M. B. Miles, \& Huberman, A. M. Qualitative Data Analysis: A Sourcebook of New Methods. (California. SAGE publications Inc, 1984), 23. 
dihasilkan produk model ibadah dan liturgi sekolah minggu bagi generasi Alfa Pada Gereja Toraja.

\section{Hasil Dan Pembahasan}

\section{Pengaruh Revolusi Industri 4.0 terhadap Karakter dan Kebutuhan Generasi Alfa}

Revolusi indstri 4.0 adalah suatu fenomena yang cukup viral dan sangat sering didengar pada masa kini. Revolusi Industri 4.0 adalah pembaharuan di bidang industri dimana kegiatan produksi dari suatu industri beroperasi dengan cepat dengan ciri utama yaitu mengandalkan internet sebagai tonggak utama. Peralatan-peralatan industri dibantu dengan sensor-sensor canggih sehingga dapat berkomunikasi sendiri dan otomatis dengan sistem teknologi informasi sehingga pada hasilnya perangkat-perangat tersebut dapat beroperasi dengan sendirinya. ${ }^{13}$ Dampak Revolusi Industri 4.0 dirasakan secara global dan berimbas mengubah kehidupan manusia. Inovasi-inovasi melalui proses digitalisasi dan otomatisasi merupakan arah perubahan kehidupan manusia pada era ini. ${ }^{14}$ Revolusi Industri memberikan dampak yang signifikan terhadap kehidupan manusia secara keseluruhan, terkhusus di Indonesia.

Era revolusi industri 4.0 tidak hanya berdampak secara global namun era revolusi ini memiliki ciri khas yang kuat yaitu mendisrupsi segala sektor kehidupan manusia. Disrupsi merupakan suatu keadaan yang menjadi fenomena terkhusus banyak terjadi di kalangan bisnis. Konse tradisional yang menekankan owning atau kepemilikikan baik omset atau kekuasaanmenjadi sharing atau konsep untuk saling berkolaborasi, contoh nyata dari disrupsi di antaranya adalah taksi konvensional yang didisrupsi oleh taksi online. Meskipun Disrupsi utamanya berlaku pada bidang bisnis akan tetapi pada kenyataannya telah meluas dalam bidang lainnya seperti pemerintahan, pendidikan, politik, budaya, dan hukum. ${ }^{15}$ Salah satu dampak yang perlu diteliti adalah pada pendidikan dan karakter anak-anak pada masa kini.

Perkembangan era yang mendepankan automatisasi dan digitalisasi ini sangat berdampak besar terahadap karakter anak pada masa kini. Perkembangan teknologi informasi terjadi dengan pesat dan bersifat menyeluruh ke segala bidang. Perkembangan yang terjadi pada teknologi, pendekatan baru yang mengembangkan secara nyata, digital dan fundamental merupakan ciri utama perkembangan teknologi pada era revolusi industri 4.0.16 Berdasarkan perkembangan teknologi informasi menciptakan suatu data yang sangat besar atau disebut juga era big data. ${ }^{17}$ Era big data memberikan kemudahan sekaligus tantangan bagi masyarakat global pada masa kini.

\footnotetext{
${ }^{13}$ Hoedi Prasetyo, dan Wahyudi Sutopo, "Perkembangan Keilmuan Teknik Industri Menuju Era Industri 4.0.”, Seminar Dan Konferensi Nasional IDEC, 2017; 488

${ }^{14}$ Hendra Suwardana, "Revolusi Industri 4.0. Berbasis Revolusi Mental”, Jurnal Jati Unik, Vol 1, No 2, 2017; 102.

${ }^{15}$ Banu PRasetyo dan Umi Trisyanti, "Revolusi Industri 4.0. dan Tantangan Perubahan Sosial," Prosiding SEATEKSOS 3, 2018; 24.

16R.RTjandrawina, ." Industri 4.0: Revolusi industri abad ini dan pengaruhnya pada bidang kesehatan dan bioteknologi." Jurnal Medicinus, Vol 29, No 1, 2016.

${ }^{17}$ J., LapiraLee, E., Bagheri, B., Kao, H., Recent Advances andTrends in Predictive Manufacturing Systems in Big DataEnvironment. Manuf. Lett. Vol 1 No 1,2013, 38-41.
} 
Akses kemudahan, kecepatan, dan digitalisasi informasi dapat dinikmati oleh setiap orang. Hal ini juga mempengaruhi dalam pengambilan keputusan cerdas, sehingga komunikasi secara interpersonal pada era revolusi industri 4.0 sangat berubah. Komunikasi secara interpersonal adalah hal penting yang perlu dikembangkang dalam era revolusi industri 4.0.18 Pengembangan ini juga termasuk komunikasi dalam pendidikan anak. Diana dalam penelitiannya juga menegaskan bahwa pendidikan orang tua kepada anak harus menekankan teladan pada era revolusi industri 4.0. Meskipun era senantiasa berubah namun pendidikan anak adalah mandat yang tetap diberikan Allah kepada setiap orang tua. ${ }^{19}$ Berdasarkan hal tersebut pendidikan anak sangat penting pada era ini.

Revolusi Industri 4.0 ditandai dengan proses industri yang mengepankan otomatisasi dan digitalisasi melalui internet. Era ini memiliki sifat yang bersifat disprupsi dan penekanan pada sharing atau tindakan yang bersifat koaboratif agar dapat bertahan pada era ini. Revolusi Industri ditandai dengan meningkatnya perkembagnan teknologi informasi sehingga disebut era big data setiap individu dapat mengasi informasi dengan mudah dan cepat dimanapun dan kapanpun asal tersedianya internet. Pada era revolusi Industri 4.0. generasi yang terkena dampak adalah generasi yang disebut generasi $\mathrm{z}$ dan generasi alfa. Meski berbeda sebutan akan tetapi memiliki sifat dan karakter yang hampir mirip namun secara ukuran usia keduanya dapat dibedakan.

Revolusi Industri yang berdampak pada generasi alfa mengkibatkan hal ini secara khusus berdampak pada anak-anak sekolah minggu pada masa kini. Anak-anak sekolah minggu pada masa kini merupakan generasi alfa yang terpengaruh adanya digitalisasi dan automatisasi efek dari era revolusi industri 4.0. Fenomena tersebut dapat dilihat dari anak-anak sekolah minggu yang sudah melek dengan gawai dan sudah pintar dengan sendirinya dalam menggunakan gawai tersebut. Era Revolusi industri sangat berpengaruh signifikan pada sekolah minggu pada masa kini. Tantangan ini tidak bisa dibendung lagi.

Generasi alfa merupakan generasi kelahiran antara tahun 2010-2025. Generasi alfa merupakan generasi yang lahir setelah generai z yaitu kelahiran antara tahun 19952009. Generasi ini tidak terlalu memiliki perbedaan yang signifikan. ${ }^{20}$ Ciri khas dari generasi ini adalah generasi yang terpapar oleh teknologi. Generasi ini secara kontinu terpapar oleh perkembangan teknologi. Generasi ini merupakan generasi yang sangat memahami dunia digital sedari usia dini. Kebiasaan dan kemudian generasi ini dalam mengakses data mengakibatkan generasi ini memiliki kecendrungan untuk tidak mengenal proses dan terbiasa dengan hal-hal yang instan dan cepat. Generasi ini juga

\footnotetext{
${ }^{18}$ Naomi Sampe, “Komunikasi Interpersonal Keluarga Kristen Memasuki Era 4.0”, Jurnal Bia.Vol 2,No 1, (2019), 72-82.

${ }^{19}$ Ruat Diana, "PRinsip Teologi Kristen Pendidikan Orang Tua terhadap anak di Era Revolusi Industri 4.0”, Jurnal Bia.Vol 2,No 1, (2019), 27-39.

20M. McCrindle, .The ABC of XYZ.(Australia:UNSW Press.2011)
} 
memiliki sifat berpikir kritis namun memiliki kecenderungan untuk hidup secara individualistis dan antisosial. ${ }^{21}$ Generasi ini adalah generasi yang mendominasi di sekolah minggu pada masa kini.

\begin{tabular}{|c|c|c|}
\hline Label Generasi & Periode & Karakteristik \\
\hline & & $\begin{array}{l}\text { tingkah laku negatif, mengenal musik punk, dan mencoba } \\
\text { menggunak- an ganja. Gen X memiliki kecende-rungan un- } \\
\text { tuk mandiri dalam berpikir. }\end{array}$ \\
\hline GENERASI Y & 1981-1994 & $\begin{array}{l}\text { Lebih banyak menggunakan teknologi komuni- kasi instan } \\
\text { seperti email, SMS, dan media sosial seperti Facebook dan } \\
\text { Twitter. Mereka juga suka game online. Saat muda, mereka } \\
\text { bergantung pada kerja sama kelompok. Kerika dewasa gen- } \\
\text { erasi ini menjadi lebih bersemangat bekerja secara berke- } \\
\text { lompok terutama di saat-saat kritis. }\end{array}$ \\
\hline GENERASI Z & $1995-2010$ & $\begin{array}{l}\text { Memiliki kesamaan dengan generasi Y, namun generasi ini } \\
\text { mampu mengaplikasikan setiap kegiatan dalam satu waktu } \\
\text { seperti: men-tweet menggunakan ponsel, browsing, dan } \\
\text { mendengar- kan musik menggunakan headset. Mereka ada- } \\
\text { lah generasi digital yang menggemari teknologi informasi } \\
\text { dan berbagai aplikasi komputer. }\end{array}$ \\
\hline GENERASI ALPHA & 2011-2025 & $\begin{array}{l}\text { Generasi yang paling akrab dengan teknologi digital dan } \\
\text { generasi yang diklaim paling cerdas dibanding generasi- } \\
\text { generasi sebelumnya. }\end{array}$ \\
\hline
\end{tabular}

Gambar 1: Tabel Label Generasi ${ }^{22}$

Menurut Mark Mc Crindle generasi ini adalah generasi yang tidak dapat lepas dari gawai, sangat kuang dalam hal sosialisasi, memiliki daya kreativitas yang rendah, dan memiliki sikap yang individualistis. Akibat dari kecenderungan itu menghasilkan generasi yang nantinya akan teralineasi secara sosial. ${ }^{23}$ Kecenderungan karakteristik generasi alfa karena pengaruh revolusi Industri 4.0 diantaranya adalah: pertama, generasi ini adalah generasi yang bossy, suka mengatur, dan cendrung dominan. Kedua, generasi ini tidak memiliki kesukaan untuk berbagi dan lebih mengutamakan kepemilikan pribadi. Ketiga, generasi ini adalah generasi yang tidak suka untuk taat dengan aturan. Keempat, Generasi ini tidak dapat lepas dari teknologi. Kelima, kemampuan sangat berkurang dalam berkomunikasi. ${ }^{24}$ Generasi alfa adalah generasi yang akan melanjutkan kehidupan bangsa indonesia. Berdasarkan pengaruh revolusi industri 4.0 dan pengaruhnya terhadap karakter generasi alfa, pendidikan rohani pada anak-anak generasi alfa sangat penting untuk dilakukan.

\section{Sekolah Minggu di Gereja Toraja}

Gereja sebagai pusat pendidikan Kristen bertanggung jawab melaksanakan pendidikan Kristen seutuhnya bagi seluruh jemaat baik terhadap orang dewasa maupun terhadap anak-anak.Sekolah minggu merupakan salah satu bentuk layanan pendidikan Kristen yang dilaksankan oleh gereja dalam rangka pembinaan kerohanian anak agar dapat mengenal Yesus Kristus sebagai Tuhan dan Juruselamatnya. Harry M. Pilland berkata sekolah minggu merupakan wadah pelayanan yang penting dalam menjangkau orang-

\footnotetext{
${ }^{21}$ Marrisa Leviani Indrayana et al, “Perancangan Buku Interaktif Pembelajaran Pengembangan Karakter Pada Generasi Alfa”, Jurnal DKV Adiwarna, Vol 1, No 12, (2018), 1

${ }^{22}$ Sigit Purnama, "Pengasuhan Digital untuk Anak Generasi Alpha", Jurnal Al Hikmah Proc Islamic Ear Child Educ, Vol 1 (Aprili, 2018), 497.

${ }^{23}$ M. McCrindle, .The ABC of XYZ.(Australia:UNSW Press.2011)

${ }^{24}$ Sigit Purnama, "Pengasuhan Digital untuk Anak Generasi Alpha”, Jurnal Al Hikmah Proc Islamic Ear Child Educ, Vol 1 (Aprili, 2018), 497-498.
} 
orang bagi Kristus dan mengembangkan mereka menjadi seperti Dia. ${ }^{25}$ Senada dengan itu, Lawrence 0 . Richard, berkata sekolah minggu adalah wadah yang memberi pelayanan kepada anak-anak dengan menjalankan fungsinya sebagai suatu komunitas iman bagi anak-anak yang di dalamnya anak belajar tentang firman Tuhan untuk semakin mengenal karya Kristus dalam hidupnya. ${ }^{26}$ Keberadaaan sekolah minggu sangat berpengaruh terhadap pertumbuhan spiritualitas anak. Kata Ralph Riggs, "dari segala ladang injil, sekolah minggu adalah ladang yang paling subur. Tujuh puluh lima persen dari semua pertobatan terjadi pada pada murid-muridsekolah minggu yang berusia 10-12 tahun, dan kebanyakan dari dua puluh lima persen yang tersisa pada orang dewasa yang pada masa mudanya mengikuti sekolah minggu". ${ }^{27}$ Sekolah Minggu merupakan tempat pendidikan agama Kristen yang sangat penting bagi pertumbuhan rohani anak-anak.

Sekolah Minggu Gereja Toraja disingkat SMGT dibentuk dengan kesadaran bahwa anak adalah gereja itu sendiri di mana jemaat sebagai gereja bertanggung jawab penuh atas pelayanan anak-anak sesuai spesifiknya dan tanggung jawab tersebut diwujudkan dalam bentuk pelayanan yang membawa anak-anak pada pengakuan iman "Yesus Kristus itulah Tuhan dan Juruselamat". ${ }^{28}$ Atas dasar tersebut, Gereja Toraja dalam mewujudkan pelayanan kepada anak-anak membentuk suatu wadah persekutuan dan pemberdayaan anak yang di sebut Sekolah Minggu Gereja Toraja (SMGT). Pelayanan ini telah dimulai sejak zaman Zending yakni Zondaagschool atau Sekolah hari minggu yang kemudian pada tahun 1955 dalam sidang sinode Am Gereja Toraja V yang dilaksanakan pada tanggal 26 Februari - 5 Maret 1955 mendapatkan perhatian yang serius dan terus digumuli di kalangan Gereja Toraja.

Kehadiran SMGT sebagai salah satu pelengkap organisasi intra gerejawi di kalangan gereja Toraja merupakan bagian yang tidak terpisahkan dari Gereja Toraja karena itu dasar SMGT ialah Alkitab dan pengakuannya dirumuskan sesuai dengan pengakuan iman Gereja Toraja yakni "Yesus Kristus Itulah Tuhan dan Juruselamat". ${ }^{29}$ Dari penjabaran tersebut tampak jelas bahwa Gereja Toraja sungguh-sungguh memahami bahwa anak adalah pewaris kerjaan Allah yang perlu dibimbing secara khusus untuk sampai pada pengakuan Iman sebagaimana amanat Kristus kepada orang percaya.

Dalam lingkup Gereja Toraja, anggota SMGT terdiri dari anak sekolah minggu gereja toraja usia 0-15 tahun dan pengurus sekolah minggu. Dalam pengkategoriannya, SMGT terdiri dari kelas bayi (0-2 tahun), kelas balita (3-5 tahun), kelas anak kecil (6-8 tahun), kelas anak besar (9-11 tahun) dan kelas anak remaja (12-15) tahun. Pada kelas kelas

${ }^{25}$ Harry M. Pilland, Perkembangan Gereja Dan Penginjilan Melalui Sekolah Minggu (Bandung:Lembaga Literatur Baptis, 1984), 7.

${ }^{26}$ Lawrence O. Richard, Pelayanan Kepada Anak-anak Mengayomi Kehidupan Iman Dalam Keluarga Allah (Bandung:Yayasan Kalam Hidup, 1996), 26.

${ }^{27}$ Ralph Riggs, Sekolah Minggu Yang Berhasil (Malang:Gandum Mas, 1983), H.3

28Pengurus Pusat SMGT, Tata Kerja \& Undang-undang Perlindungan Anak, (Rantepao: 2014)h.1

${ }^{29}$ Ibid. 
SMGT tersebut, inisiasi dilakukan pada setiap peralihan kelas. Pelayananan kepada anak SMGT juga menggunakan model liturgi yang telah disusun untuk masing-masing kelas. Liturgi yang diambil adalah untuk kelas besar antara usia 9-11 tahun, yaitu:

- Persiapan (mempersiapkan perlengkapan ibadah, mengenakan stola, ucapan selamat datang, sapaan dan memberi salam kepada anak sekolah minggu)

- Prosesi

- Votum

- Menyanyi

- Percakapan pendek (Percakapan pendek tentang keadaan anak, pembahasan cerita minggu lalu)

- Pengakuan dosa dan berita anugerah

- Petunjuk Hidup Baru

- Bermazmur

- Pemberitaan Firman (Doa PA/berdoa dalam bentuk nyanyian, bercerita)

- Doa Bapa Kami

- Persembahan

- Ayat hafalan (memberi ayat hafalan)

- Aktivitas

- Doa syafaat

- Pengutusan dan berkat (menyanyi, berkat, menyanyi sambil bersalaman)

Liturgi ini menjadi tuntunan praktis bagi setiap guru-guru sekolah minggu untuk melaksanakan proses ibadah sekolah minggu di setiap gereja Toraja.

Anak umur 9-11 tahun merupakan disebut juga kelas besar. Pada range ini jumlah anak cukup signifikan ketika datang sekolah minggu dan sudah mulai memiliki kesadaran untuk sekolah minggu. SMGT di jemaat Tampo untuk anak umur tersebut berjumlah antara 20-30 anak ${ }^{30}$ dan SMGT di jemaat Minanga untuk umur tersebut berjumlah sekitar 20 anak. ${ }^{31}$ Jumlah tersebut dari jumlah total anak-anak SMGT sekitar 80-an anak dalam setiap ibadahnya. Berdasarkan data tersebut jumlah anak-anak generasi alfa yang berumul 9-11 merupakan jumlah yang cukup signifikan di Gereja Toraja.

\section{Metode Sekolah Minggu Mebig Jepang dan Superbook}

Mebig Jepang adalah pelayanan sekolah minggu secara kreatif di jepang yang memfokuskan pada pemuridan. Mazmur 127:3-4 "Sesungguhnya anak-anak lelaki adalah milik pusaka dari pada Tuhan, dan buah kandungan adalah suatu upah. Seperti anak panah di tangan Pahlawan, demikianlah anak-anak pada masa muda". Mebig Jepang memaknai bahwa anak-anak adalah milik pusaka, upah yaitu pelayanan yang murni kepada anak dan pada akhirnya anak-anak kan menjadi senjata atau kekuatan bagi orang dewasa. ${ }^{32}$

Mebig adalah pelayanan yang mengedepankan konsep memory, bible dan game. Game atau permainan menjadi fokus dalam pendidikan anak atau sekolah minggu Mebig. Pentingnya bermain bagi anak adalah; pertama hal tersebut merupakan berkat

30Intan Nidyananda, Wawancara, Toraja, Indonesia, 12 Desember 2019.

31Yiska Winda Paibing, Wawancara, Toraja, Indonesia, 12 Desember 2019.

32Teppei Yama, "Pemuridan Yang Terfokus Pada Pelayanan Anak Di Era Digital", prosiding seminar nasional tahun 2018: pelayanan anak : perbesardaya kreatif pelayanan anak zaman digital. 2018; 18 
Tuhan yang diekpresikan melalui permainan, menari, dan melompat. Kedua, permainan yang aktif mewujudkan kondisi bersama Tuhan. Ketiga, permainan memberikan rasa menyenangkan pada anak-anak sehingga mereka dapat merasakan kebahagiaan. Keempat, permainan merupakan tanda pertobatan bagi anak-anak. Kelima, permainan merupakan tanda kehidupan bagi seorang anak. Dampak bermain dalam ibadah sekolah minggu dapat mendorong stimulus pertumbuhan dan perkembangan anak menjadi lebih baik selain hal tersebut hal ini juga dapat menarik minat anak-anak dalam mendengarkan kebenaran Firman Tuhan. Permainan dalam mebig adalah suatu prioritas dalam mengenalkan Kristus. ${ }^{33}$

Pentingnya bermain bagi anak-anak adalah untuk menjadikan dasar hidup yang kuat. Bermain merupakan sarana pertumbuhan otak yang maksimal. Sejak awal kelahiran anak-anak yang bisa dilakukan adalah bermain. Proses bermain itu dilakukan oleh Ibu dan bayinya. Bermain merupakan dasar sarana pentingya pertumbuhan otak anak. ${ }^{34}$ Mebig mendasari sekolah minggu dengan menggunakan permainan untuk memaksimalkan pertumbuhan dan perkembangan anak. Permainan dalam mebig merupakan permainan sederhana yang merupakan permainan wajar dilakukan oleh anak-anak pada usia tersebut. Beberapa jenis permainan tersebut seperti berlari-lari, melompat, jongkok, dan permainan mengasyikan lainnya.

Gelombang otak yang terpapar gawai menjadikan anak-anak memiliki pola pertumbuhan visual yang mengakibatkan hasil rekaman electroence-phalograph (EEG) jauh dari range normal. Gelombang otak alfa dan beta yang jauh dari range normal pada anak-anak akan berimbas pada kehidupan anak pada masa dewasa dalam hal pengambilan keputusan maupun berpikir kreatif. Gelombang otak yang demikian adalah gelombang otak yang dimiliki oleh penderita alzheimer. Kondisi gelombang beta normal akan membuat manusia mudah melakukan analisis dan penyusunan informasi, membuat koneksi, dan menghasilkan solusi-solusi serta ide-ide baru.Kondisi gelombang alpha normal akan membuat relaks dan mendorong aliran energi kreativitas, perasaan segar, dan sehat. ${ }^{35}$

${ }^{33}$ Akiko Ito, "Permainan Menjadi Prioritas Dalam Mengomunikasikan Kristus Di Era Digital,"Prosiding seminar nasional tahun 2018: pelayanan anak : perbesardaya kreatif pelayanan anak zaman digital. 2018; 13-15

${ }^{34}$ Teppei Yama danAkiko Ito, "Pertobatan dan Pertumbuhan Anak(Prinsip Dan Metode Meningkatkan Kemampuan GuruDi Era Digital)”, prosiding seminar nasional tahun 2018: pelayanan anak : perbesardaya kreatif pelayanan anak zaman digital. 2018; 5

${ }^{35}$ Akiko Ito, "Permainan Menjadi Prioritas Dalam Mengomunikasikan Kristus Di Era Digital,"Prosiding seminar nasional tahun 2018: pelayanan anak : perbesardaya kreatif pelayanan anak zaman digital. 2018; $10-11$ 


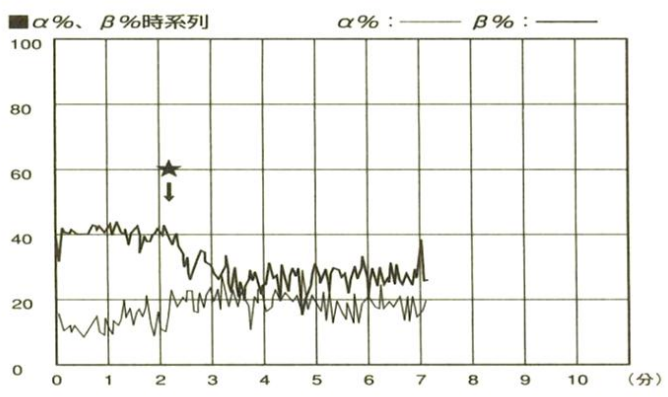

\section{Gambar 2: Gelombang otak tipe manusia berotak visual}

Permainan dalam sekolah minggu merupakan hal penting yang perlu untuk dikerjakan. Permainan sangat berdampak luas bagi pertumbuhan anak. Permainan dalam mebig juga dapat meningkatkan daya tarik sekolah minggu sehingga anak senantiasa termotivasi dan tertarik untuk mengikuti sekolah minggu.

Model lainnya dalam sekolah minggu adalah superbook. Superbook mengedepankan film dan animasi dalam mengomunikasikan Kristus. ${ }^{36}$ Masyarakat terkhusus anak-anak zaman sekarang yang terpapar revolusi industri 4.0 cenderung lebih menyukai tayangan film. Terkhusus anak-anak lebih menyukai gambar-gambar yang bergerak dan terdiri atas berbagai macam warna yang sangat menarik perhatian anak. Bahasa yang digunakan dalam filmpun memiliki kelebihan yaitu mudah untuk di terima oleh anakanak pada masa kini. ${ }^{37}$ Metode superbook ini tepat untuk diberikan pada anak generasi alfa.

Pada generasi $\mathrm{Z}$ tantangan yang dialami untuk pergi ke sekolah minggu adalah karena adanya film animasi. Televisi sering kali menghadirkan tanyangan animasi pada minggu pagi sehingga hal ini sangat mempengaruhi motivasti anak-anak untuk pergi ke sekolah minggu. Seperti televisi yang meningkatkan ratingnya melalui film- film animasi maka daya tarik sekolah minggu dapat juga ditingkatkan melalui film-film animasi. Hal ini merupakan suatu peluang yang dapat dilakukan oleh Guru-guru sekolah minggi pada masa sekarang. Guru-guru sekolah minggu tetap harus dapat menyampaikan kebenaran Firman Tuhan secara kretif dan interaktif sesuai dengan kebutuhan anak pada masa sekarang terkhusus pada anak generasi alfa. Cara untuk menyampaikan secara kreatif dan interaktif ini dapat dilakukan dengan menggunakan media audio-visual yaitu melalui film. ${ }^{38}$

Superbook dapat digunakan oleh guru-guru sekolah minggu pada masa sekarang agar anak tertarik mengikuti sekolah minggu, sehingga para guru dapat menyampaikan FirmanTuhan dengan optimal. Melalui pembelajaran Firman Tuhan dengan film superbookdiharapkan anak-anak terus tertarik dan memiliki gaya hidup untuk

\footnotetext{
${ }^{36}$ Superbook Indonesia, "Film Superbook Indonesia" https://www.superbookindonesia.com/about/animation.html(diakses 13 Juli 2019).

37Yurika V. Bayoe, Meily L.Kouwagam, Parel Tanyit, "Metode Pembelajaran Melalui FIlm Superbook dan Minat Belajar Firman pada Anak Usia 6-8 Tahun”, Jurnal Jaffray, Vol. 17, No. 1, 2019;143

${ }^{38}$ Ana Setyandari, "Inovasi Pemanfaatan Media Film Untuk Peningkatan Kemampuan Listening Dalam Pembelajaran Bahasa Inggris," Jurnal Magistra XXVII, no. 91 (Maret 2015); 45
} 
mempelajari kebenaran Firman Tuhan. Superbook menghadirkan film-fil yang dikemas secara menarik. Film ini diproduksi oleh pelayanan CBN. Superbook menceritakan petualangan -petualangan ketika bertemu dengan tokoh-tokoh Alkitab dalam bentuk animasi. Melalui cerita petualangan yang dikemas dalam animasi ini yang dapat mengomunikasikan Kristus dengan kreatif kepada anak anak pada masa sekarang terkhusus pada anak generasi alfa. ${ }^{39}$

Pengembangan pembelajaran yang bersifat aktif, kreatif, dan inovatif juga dikembangkan oleh Bernawy Munthe. Pembelajaran aktif, kreatif, dan inovatif sangat penting bagi dunia pendidikan masa kini karena merupakan salah satu alternatif solusi terhadap integrasi guru, murid, dan strategi. ${ }^{40}$ Pembelajaran kreatif-interaktif yang akan disusun menggubungkan konsep Mebig dan Supperbook dengan prinsip-prinsip pembelajaran aktif, kreatif, dan inovatif.

\section{Analisisis Interaktif}

Analisis interaktif adalah analisis dengan menggunakan teknik pengumpulan data, reduksi data, dan penarikan kesimpulan dari data-data yang telah didapatkan. Pengumpulan data telah dideskripsikan dalam bentuk narasi kemudian dilakukan proses reduksi hingga didapatkan penarikan kesimpuan. Reduksi dan penarikan kesimpulan di sajikan dalam bentuk tabel sebagai dassar pembuatan produk.

Tabel 1: Analis Interaktif pembuatan Produk

\begin{tabular}{|c|c|c|c|}
\hline No & Gereja Toraja/Tesis & $\begin{array}{c}\text { Antitesis/Generasi Alfa } \\
\text { dan pengembangan } \\
\text { metode sekolah Minggu }\end{array}$ & Kesimpulan \\
\hline 1 & $\begin{array}{l}\text { Sekolah minggu Gereja } \\
\text { Toraja menggunakan } \\
\text { liturgis dan yang sudah } \\
\text { ditetapkan dan Firman } \\
\text { Tuhan disampaikan } \\
\text { dengan bercerita, } \\
\text { nyanyian, atau ceramah. }\end{array}$ & $\begin{array}{l}\text { Metode permainan dalam } \\
\text { mennyampaikan Firman } \\
\text { Tuhan } \\
\text { Metode supperbook } \\
\text { dengan menggunakan } \\
\text { Film animasi }\end{array}$ & $\begin{array}{l}\text { Mengombinasikan liturgis } \\
\text { sekolah minggu Gereja Toraja } \\
\text { dengan permainan atau film } \\
\text { animasi secara kreatif dan } \\
\text { interaktif dalam hal } \\
\text { penyampaian/pembelajaran } \\
\text { Firman Tuhan. }\end{array}$ \\
\hline 2 & $\begin{array}{l}\text { SMGT terdiri dari anak } \\
\text { sekolah minggu gereja } \\
\text { toraja usia 0-15 tahun }\end{array}$ & $\begin{array}{l}\text { Generasi alfa yang } \\
\text { terpapar teknologi dan } \\
\text { memiliki karakterisitik } \\
\text { antisosial dan } \\
\text { individualis }\end{array}$ & $\begin{array}{l}\text { Anak-anak SGT di Gereja } \\
\text { Toraja merupakan generasi } \\
\text { alfa. }\end{array}$ \\
\hline
\end{tabular}

\section{Pembuatan Produk}

Produk yang dihasilkan melalui analisis di atas adalah suatu buku pedoman pembelajaran sekolah minggu kreatif inovatif. Buku tersebut dihasilkan dari analisis dengan garis besar yang meliputi Penjelasan, Prinsip, dan Metode sekolah minggu kreatif dan interaktif. Secara garis besar penelitian ini menghasilkan produk sebuah buku yang di deskripsikan sebagai berikut.

\footnotetext{
${ }^{39}$ Superbook Indonesia, "Film Superbook Indonesia" https://www.superbookindonesia.com/about/animation.html(diakses 13 Juli 2019).

40Bernawy Munthe, StrategiMengajar Aktif Kreatif Inovatif, (Yogyakarta: uka Press,2017),7
} 
Pertama, penjelasan model sekolah minggu kreatif-interaktif bagi generasi alfa kepada Gereja Toraja. Model ini merupakan model yang di khususkan untuk generasi alfa pada gereja Toraja pada masa kini. Model kreatif-interaktif merupakan model yang didasari untuk menciptakan model pembelajaran yang menarik sehingga murid-murid sekolah minggu senantiasa datang dan termotivasi untuk mengikuti sekolah minggu. Model ini secara kreatif menggunakan pemanfaatan permainan (game) dan pemanfaatan kemaujan teknologi informasi sehingga didaharapkan adanya suatu interaksi yang menyenangkan antara Guru dan murid sekolah minggu. Harapan dan dampak yang dihasilkan adalah murid sekolah minggu termotivasi untuk belajar kebenaran Firman Tuhan dan Firman Tuhan tersebut tersampaikan secara maksimal kepada murid-murid sekolah minggu terkhusus generasi alfa. Model ini juga tidak menutup kemungkinan untuk dipraktikan ataupun diimplementasikan pada sekolah minggu selain Gereja Toraja.

Kedua, prinsip-prinsip model sekolah minggu kreatif-interaktif bagi generasi alfa kepada Gereja Toraja. Prinsip-prinsip tersebut diistilahkan prinsip kolaboratif dan prinsip konfrontatif. Pengertian prinsip kolaboratif yaitu dengan menekankan penggunaan teknologi informasi dalam pembelajaran Firman Tuhan terkhusus penggunaan internet, youtube, ataupun media sosial lainnya. Pengertian prinsip konfrontatif adalah penggunan permainan dalam pembelajaran Firman Tuhan pada sekolah minggu. Kedua prinsip ini yang mendasari metode/langkah-langkah penyampaian Firman Tuhan dan dilakukan secara bergantian sehingga sekolah minggu akan bervariasi dan tidak monoton. Pertimbangan penggunaan prinsip kolaboratif adalah karena hal ini merupakan dunia generasi alfa dan pengaruh revolusi industri 4.0 yang tidak akan bisa lepas dari perkembangan teknologi informasi. Pertimbangan penggunaan prinsip konfrontatif adalah untuk memaksimalkan tumbuh kembang anak sehingga tidak menjadi pribadi yang antisosial dan individualis serta pertumbuhan otak yang mamaksimal sehingga dapat berpikir kreatif dan mengambil keputusan dengan benar. Penggunaan dua prinsip ini secara seimbang akan sangat berpengaruh baik untuk kemajuan sekolah minggu di Gereja Toraja.

Ketiga, metode sekolah minggu kreatif-interaktif bagi generasi alfa pada Gereja Toraja. Metode yang dilakukan adalah memasukan prinsip kolaboratif ataupun konfrontatif pada penyampaian Firman sedangkan liturgi sekolah minggu Gereja Toraja tidak di ubah. Hal ini juga untuk menyiapkan dan membiasakan anak-anak untuk beribadah di Gereja Toraja sesuai dengan liturgi yang ada. Metode ini dituliskan dalam strategi dengan langkah-langkah yang rinci pada bab di produk yaitu buku sekolah minggu.

Salah satu contoh metode prinsip konfrontatif yaitu dengan menggunakan permainan yaitu, game make a puppet character. Anak-anak sekolah minggu dibagi dalam kelompok-kelompok. Guru sekolah minggu yang akan menyampaikan kebenaran Firman Tuhan menyuruh kelompok -kelompok tersebut membuat boneka wayang dari kertas. Kelompok 1 diminta membuat tokoh raja, kelompok dua tokoh prajurit yang 
kuat dan besar, tokoh tiga seorang biasa yang keci, kelompok empat membuat dombadomba dan tokoh laiinya yang dirasa perlu. Anak-anak diberikan waktu untuk membuat karakter tersebut. Setiap kelompok memberikan deskripsi singkat setelah kharakter tersebut jadi. Berdasarkan karakter-karakter boneka wayang tersebut Guru sekolah minggu menceritakan kisah daud melawan goliat dengan singkat. Di akhir cerita anakanak diberikan pertanyaan dan yang dapat menjawab diberikan reward.

Salah satu contoh metode prinsip kolaboratif yaitu dengan memanfaatkan media sosial youtube, yaitu guest meaning of cover song. Anak-anak dibagi dalam kelompokkelompok dan Guru sekolah minggu memberikan satu buah lagu cover song dapat diberikan lewat handphone atau layar LCD di depan melalui streaming youtube. Contohnya Guru sekolah minggu memilihkan cover song "seindah siang". anak-anak diminta setiap kelompok untuk memahmi lirik dan menyanyikan. Setiap kelompok menyanyikan dan memberikan tanggapan mengenai lagu tersebut. Kelompok yang terbaik diberikan hadiah daan kemudian disambung guru memberikan penjelasan Firman yang tepat secara singkat sesuai dengan lagu tersebut.

Produk buku sekolah minggu kreatif-interaktif bagi generasi alfa pada Gereja Toraja memiliki garis besar sepeti di atas. Langkah selanjutnya adalah pengembangan dari buku ini dengan penilaian dari Merry Adeng untuk sebagai pemberi masukan mengenai ketepatan metode kreatif-interaktif yang digunakan dan Christian Randale dalam hal ketepatan dengan konteks generasi alfa pada penyusunan liturgi sekolah minggu Gereja Toraja.

\section{Pengembangan Produk}

Pengembangan dilakukan dengan melakukan kritisi terhadap produk yang telah diterbitkan. Proses kritisi dilakukan oleh dua partisipan secara kualitatif untuk memberikan masukan dan perbaikan untuk produk yang telah dihasilkan. Hasil dari kritisi dan rekomendasi langsung digunakan untuk pengembangan produk buku Sekolah Minggu Kreatif-Inovatif. Berdasarkan segi kreatifitas produk yang dihasilkan cukup menarik, mudah diaplikasikan dan metode yang dipaparkan dapat menciptakan pembelajaran yang kreatif dan inovatif akan tetapi pengajar sekolah minggu harus lebih "tahu" dari anak sehingga perlu adanya program peningkatan mutu guru sekolah minggu melalui pelatihan-pelatihan maupun seminar. ${ }^{41}$

Beberapa kelemahan dalam metode kolaboratif yang disoroti adalah penggunaan media social youtube yang cukup besar porsinya.Hal ini juga perlu pertimbangan dikarenakan pengajar sekolah minggu harus membekali ilmu mengenai penggunaan youtube. Penggunaan youtube oleh generasi alfa juga perlu mempertimbangankan umur dari anak-anak sehingga guru sekolah minggu harus tahu benar usi anak yang tepat untuk mandiri dan bertanggungjawab saat menjelajah youtube. Berdasarkan hal tersebut perlu adanya perbaikan yaitu penambahan jenjang usia pada produk buku

41Merry Adeng, Wawancara, Toraja, Indonesia, 12 Agustus 2019. 
Sekolah Minggu Kreatif-Inovatis sehingga dengan memperhatikan usia yang tepat diharapkan anak dapat berkompetisi dan menggunakan youtube secara bertanggung jawab. ${ }^{42}$

Perbaikan dari buku ini juga perlu diperhatikan dari sisi aspek pengajar dimana untuk menyiapkan materi harus memperhatikan kemudahan serta dapat menjangkau segala usia anak agar dapat bersosialisasi dengan senior dan junior mereka dalam ibadah sekolah minggu. Secara garis besar metode ini dapat dikembangkan secara luas dan memberikan daya tarik tersediri sehingga metode pembelajaran yang dialami oleh anak-anak sekolah minggu berbeda dengan metode pembelajaran yang ada di sekolah formal pada umumnya. Kerja keras dari guru sekolah minggu harus membawa anak menjadi aktif melalui pembelajaran kreatif inovatif ini. ${ }^{43}$

Pengembangan dari sisi anak sekolah minggu Gereja Toraja yang mulai sekarang didominasi oleh generasi alfa merupakan kelahiran 2010 ke-atas. Generasi ini di Gereja Toraja juga sangat tertarik dengan kemajuan gawai sehingga prioritas mereka dalam bermain adalah menggunakan gawai. Berdasarkan hal tersebut buku ini sangat tepat untuk menambahkan keterampilan dan kognisi dari guru sekolah minggu dalam mengembangkan metode pembelajarannya. ${ }^{44}$

Buku ini tepat untuk pembaharuan yang dilakukan adalah bagian pembelajaran Firman, mengingat bahwa masih tercampurnya generasi-generasi yang ada di dalam Gereja Toraja sehingga sekolah minggu Gereja Toraja bukan menjadi sekolah minggu yang tidak ramah dengan tradisi Gereja Toraja namun tetap ramah akan tetapi terdapat pengembangan dari hal pembelajaran Firman Tuhan terkhusus pada sekolah minggu. Melalui hal ini sekolah minggu Gereja Toraja tetaplah Sekolah Minggu yang bercirikan ciri khas ajaran-ajaran Gereja Toraja. ${ }^{45}$

\section{Kesimpulan}

Berdasarkan hasil dari penelitian dan pengembagan kajian ini didapatkan hasil sebuah produk yaitu buku Sekolah Minggu Kreatif-Inovatif yang menjawab kebutuhan generasi alfa pada sekola minggu Gereja Toraja. Model Kreatif-Inovatif menggunakan prisip kolaboratif dan konfrontatif dalam pengajaran Firman Tuhan sehingga sekolah minggu Gereja Toraja dapat menjawab semua kebutuhan rohani anak-anak generasi alfa pada Gereja Toraja. Model ini dapat diaplikasikan oleh guru-guru sekolah minggu Gereja Toraja sehingga dapat menghasilkan pengembangan pembelajaran Firman Tuhan dalam keseluruhan Sekolah Minggu Gereja Toraja. Saran dari penelitian ini adalah perlu diadakannya penelitian lanjutan secara kuantitatif mengenai daya tarik dan daya serap anak generasi alfa terhadap pembelajaran Firman Tuhan pada sekolah minggu Generasi Alfa Gereja Toraja sehingga diketahui efektifitas dari model ibadah sekolah minggu Kreatif-Inovatif bagi generasi alfa Gereja Toraja. Hal ini berkaitan dengan uji

\footnotetext{
42 Ibid

43 Ibid

${ }^{444}$ Christian Eleyazar Randalele, Wawancara, Toraja, Indonesia, 04 Agustus 2019.

45 Ibid.
} 
coba produk yang dihasilkan sehingga dapat dilakukan proses revisi dan pengembangan produk kembali. Produk pada akhirnya akan senantiasa mengalami penyempurnaan dari proses uji coba yang dilakukan.

\section{Referensi}

Adeng, Merry.Wawancara, Toraja, Indonesia, 12 Agustus 2019.

Bayoe, Yurika V. Meily L.Kouwagam, Parel Tanyit. "Metode Pembelajaran Melalui FIlm Superbook dan Minat Belajar Firman pada Anak Usia 6-8 Tahun”, Jurnal Jaffray, Vol. 17, No. 1, 2019.

Diana, Ruat."Prinsip Teologi Kristen Pendidikan Orang Tua terhadap anak di Era Revolusi Industri 4.0", Jurnal Bia. Vol 2,No 1, (2019).

Gazali, Erfan. "Pesantren di Antara Generasi Alfa dan Tantangan Dunia PendidikanEra Revolusi Indrustri 4.0.,"Oasis:Jurnal Ilmiah Kajian Islam, Vol 2, No 2, (Februari, 2018).

Indrayana, Marrisa Leviani et al. "Perancangan Buku Interaktif Pembelajaran Pengembangan Karakter Pada Generasi Alfa”, Jurnal DKV Adiwarna, Vol 1, No 12, (2018).

Ito, Akiko. "Permainan Menjadi Prioritas Dalam Mengomunikasikan Kristus Di Era Digital,'Prosiding seminar nasional tahun 2018: pelayanan anak : perbesardaya kreatif pelayanan anak zaman digital. 2018.

Kharisma, Nanda Veruna Enun. "Kriteria Guru Sekolah Dasar ideal Pada Era Generasi Alfa", diakses dari nandaverunaenun.blogs.uny.ac.id/.../Kriteria-Guru-Sekolah-Dasar- 8 Juli 2019, 22.34 WIB.

Lee, J. LapiraE., Bagheri, B., Kao, H., Recent Advances andTrends in Predictive Manufacturing Systems in Big DataEnvironment. Manuf. Lett. Vol 1 No 1 (2013, 38-41)

McCrindle, M. The ABC of XYZ.Australia:UNSW Press,2011.

Miles, M. B., \& A. M. Huberman.Qualitative Data Analysis: A Sourcebook of New Methods. California. SAGE publications Inc, 1984.

Munthe, Bernawy StrategiMengajar Aktif Kreatif Inovatif, Yogyakarta: uka Press,2017.

Mutia, Tika, "Generasi Millenial, Instagram dan Dramaturgi: Suatu Fenomena dalam Pengelolan Kesan Ditinjau dari Perspektif Komunikasi Islam,” Jurnal Pemikiran Islam, Vol 41, No 2, (Desember, 2017).

Naomi, Sampe. "Komunikasi Interpersonal Keluarga Kristen Memasuki Era 4.0”, Jurnal Bia.Vol 2,No 1, (2019)

Nuhamara, Daniel. Pembimbing PAK. Bandung: Jurnal Info Media, 2007

Pilland, Harry M. Perkembangan Gereja Dan Penginjilan Melalui Sekolah Minggu. Bandung:Lembaga Literatur Baptis, 1984.

Prasetyo, Banu dan Umi Trisyanti, "Revolusi Industri 4.0. dan Tantangan Perubahan Sosial," Prosiding SEATEKSOS 3, (2018)

Prasetyo, Hoedi dan Wahyudi Sutopo. "Perkembangan Keilmuan Teknik Industri Menuju Era Industri 4.0.", Seminar Dan Konferensi Nasional IDEC,(2017).

Pengurus Pusat SMGT, Tata Kerja \& Undang-undang Perlindungan Anak, (Rantepao: 2014)

Purnama, Sigit. "Pengasuhan Digital untuk Anak Generasi Alpha", Jurnal Al Hikmah Proc Islamic Ear Child Educ, Vol 1 (Aprili, 2018).

Randalele, Christian Eleyazar.Wawancara, Toraja, Indonesia, 04 Agustus 2019.

Ralph,Riggs. Sekolah Minggu Yang Berhasil. Malang:Gandum Mas, 1983.

Richard, Lawrence O. Pelayanan Kepada Anak-anak Mengayomi Kehidupan Iman Dalam Keluarga Allah Bandung:Yayasan Kalam Hidup, 1996. 
Satya, Venti Eka."Strategi Indonesia Menghadapi Industri 4.0.”Jurnal Info Singkat: Kajian Singkat Terhadap Isu Aktual dan Strategis. Vol , No 09.(Mei, 2018).

Setyandari, Ana. "Inovasi Pemanfaatan Media Film Untuk Peningkatan Kemampuan Listening Dalam Pembelajaran Bahasa Inggris," Jurnal Magistra XXVII, no. 91 (Maret 2015).

Sugiyono.Metode Penelitian Kuantitatif, Kualitatif, dan RnD, Bandung : Alfabeta, 2009

Superbook Indonesia, "Film Superbook

Indonesia"https://www.superbookindonesia.com/about/animation.html(diakses $13 \mathrm{Juli}$ 2019).

Suwardana, Hendra. "Revolusi Industri 4.0. Berbasis Revolusi Mental”, Jurnal Jati Unik, Vol 1, No 2, (2017).

Tjandrawina, R.R. "Industri 4.0: Revolusi industri abad ini dan pengaruhnya pada bidang kesehatan dan bioteknologi." Jurnal Medicinus, Vol 29, No 1, (2016)

Wardani, Laksmi Kusuma. "Simbolisme Liturgi Ekaristi Dalam Gereja Katolik Sebuah Konsepsi dan Aplikasi Simbol", Dimensi Interior, Vol.4, No.1, (Juni 2006).

Yahya, Muhammad.”Era Industri 4.0.Tantangan dan Peluang Perkembangan Pendidikan Kejuruan Inonesia", (Orasi Ilmiah Senat Universitas Negeri Makassar,Makassar, 14 Maret 2018).

Yama, Teppei "Pemuridan Yang Terfokus Pada Pelayanan Anak Di Era Digital", prosiding seminar nasional tahun 2018: pelayanan anak : perbesardaya kreatif pelayanan anak zaman digital. 2018.

Yama,Teppei danAkiko Ito, "Pertobatan dan Pertumbuhan Anak(Prinsip Dan Metode Meningkatkan Kemampuan GuruDi Era Digital)", prosiding seminar nasional tahun 2018: pelayanan anak : perbesardaya kreatif pelayanan anak zaman digital. 2018. 